\title{
EFFECTS OF DISULFIDE BOND REDUCTION ON THE EXCITATORY AND INHIBITORY POSTSYNAPTIC RESPONSES OF APLYSIA GANGLION CELLS
}

\author{
Tadasi SAto, ${ }^{*}$ Makoto SAto,* and Masashi SAWAdA** \\ Neuroscience Laboratory, Division of Neurosurgery, University of Oregon \\ Medical School, Portland, Oregon 97201
}

\begin{abstract}
Three kinds of the cholinoceptive neurons, nicotinic depolarizing (D)-, nicotinic hyperpolarizing (H)-, and muscarinic H-types, as well as two other kinds of neurons, GABA H- and dopamine $\mathrm{H}$-types, were identified in Aplysia abdominal ganglion, and the effects of disulfide bond reduction and reoxidation on their postsynaptic responses were studied by measuring conductance change produced by each transmitter. The acetylcholine-induced responses of both nicotinic types (D- and $\mathrm{H}-$-) were depressed by reducing the disulfide bonds with dithiothreitol (DTT) and restored by reoxidizing with 5,5'-dithiobis-(2-nitrobenzoic acid): (DTNB), whereas the responses of the muscarinic H-, GABA H-, and dopamine $\mathrm{H}$-cells were not affected at all by either DTT or DTNB.

In contrast to the results obtained from the electroplax, the cholinergic receptors in our preparation showed neither the activation by hexamethonium nor the augmentation of decamethonium-induced responses after reduction of disulfide bonds. In addition, our preparation did not demonstrate the long-lasting responses to bromoacetylcholine, which was often observed in the electroplax after reduction of S-S bonds.

DTT-induced depression of the nicotinic responses was studied on the dose-response curves; the mode of receptor inhibition was rather complexed, being neither type of competitive nor non-competitive.

We concluded that the disulfide bond is a crucial element in both types of nicotinic receptors ( $\mathrm{D}$ and $\mathrm{H}$ ), and that this bond is related to the activation process of the receptors regardless of their ionic specificities.
\end{abstract}

Since KARLIN and BARTELS (1966) reported that the ACh-induced response of the electroplax, Electrophorus electricus, was inhibited markedly by the reduction

\footnotetext{
Received for publication April 22, 1976

* Present address: I Department of Physiology, School of Medicine, Iwate Medical University, Morioka 020, Japan.

** Present address: Department of Physiology, Shimane Medical College, 1134 Ootsumachi, Izumo 693, Japan.

佐藤 匡，佐藤 誠，沢田正史
} 
of disulfide bonds with DTT and restored by the reoxidation with DTNB, similar phenomena have been observed in other nicotinic preparations: rat denervated muscle (Albuquerque et al., 1968), frog rectus (MitTag and Tormay, 1970), chick biventer cervix (RANG and RITTER, 1971), frog sartorius (DEL CASTILlo et al., 1971; Ben-Haim et al., 1973), and leech muscle (Ross and Triggle, 1972). However, these phenomena were not confirmed either in the muscarinic excitatory receptors of the intestinal muscles (KUHNEN-Clausen, 1975) or in the non-cholinergic neuromuscular preparation (BEN-HAIM et al., 1973). Karlin and his coworker (KARLIN and WINNIK, 1968; KARLIN, 1969) proved that the disulfide bond was localized around $11 \AA$ from the anionic site of the ACh-receptor in the electroplax by employing site-directed thiol reagents which blocked the reoxidation of the reduced disulfide bonds. BEN-HAIM et al. (1973) examined the presence of disulfide bond within a similar location at the ACh-receptor in the frog muscle, and inferred that the disulfide bond is an exclusive element of the nicotinic receptor (compare MitTAG and TORMAY, 1970). Most of the above results, however, were obtained from the excitatory receptor of either nicotinic or muscarinic type, and little work has been made on the inhibitory type of receptors.

This paper is to study the effect of S-S bond reduction at the receptors of the inhibitory type and to compare with those of the excitatory type in the abdominal ganglion of Aplysia.

\section{MATERIALS AND METHODS}

Preparation and purfusing media. The abdominal ganglia of the Aplysia californica were used. Each ganglion contains D- and H-cells for ACh (TAUC and GERSCHENFELD, 1962) whose locations have been well analyzed and named by FrAZIER et al. (1967). Usually the nicotinic D-cells are identified in the RB group, whereas the nicotinic $\mathrm{H}$-cells are in the $\mathrm{RC}$ group. The muscarinic $\mathrm{H}$-cells are often identified in the deeper portion around the R1. The cells were exposed in the flow of perfusing media after dissecting the connective tissue covering the dorsal surface of the ganglion. The cells were normally perfused with artificial Aplysia Ringer's (SATo et al., 1968); $\mathrm{Na}^{+} 587, \mathrm{~K}^{+} 12, \mathrm{Cl}^{-} 671, \mathrm{Ca}^{++} 14$, and $\mathrm{Mg}^{++} 52 \mathrm{~mm}$. The effective perfusing volume of the chamber was $0.2 \mathrm{ml}$, and the rate of perfusion was $5 \mathrm{ml}$ per min. The $\mathrm{pH}$ of the perfusing media was adjusted to be $7.4 \pm 0.05$ with Tris (Hydroxymethyl) aminomethane and $\mathrm{HCl}$. The temperature of the perfusing media was maintained at $10^{\circ} \mathrm{C}$. Further details about the preparation have been published elsewhere (SATo et al., 1968).

Drugs. The following drugs were used for the experiment: neostigmine bromide (Neo); nicotine $2 \mathrm{HCl}$; arecoline $\mathrm{HBr}$; acetylcholine $\mathrm{Cl}(\mathrm{ACh})$; dithiothreitol (DTT) (ClelAND, 1964); 5,5'-dithiobis-(2-nitrobenzoate) (DTNB) (EllmaN, 1959); hexamethonium (Hex); decamethonium (Deca); bromoacetamide (BAA); bromoacetylcholamine bromide (BACA) (KALDERON and SILMAN, 1971); bromoacetylcholine bromide (BAC) (SILMAN and KARLIN, 1969); gamma-aminobutyric acid 
(GABA); and dopamine. These drugs were dissolved in the Aplysia Ringer's and directly applied to the cell membrane by means of microperfusion. The $\mathrm{pH}$ of the DTT and the DTNB solutions was adjusted to be $8.0 \pm 0.05$, but that of other drugs was adjusted to be $7.4 \pm 0.05$. In order to obtain the maximum response to a given concentration [A] of the drug and yet to avoid the unnecessary prolongation of the response, the drug application time $(\mathrm{T})$ was determined by an empirical equation,

$$
T=15 \times 2^{-\log [\mathrm{A}]}
$$

where $T$ and $\mathrm{A}$ are expressed in sec and $\mathrm{mm}$, respectively. The testing of the response to a given transmitter concentration was repeated after a sufficient washing time $(>5 \mathrm{~min}$ ) to eliminate the problem of receptor desensitization.

Measurement of the conductance increase. Into each of the cells were inserted two microelectrodes filled with $1.8 \mathrm{M}$ potassium citrate under binocular microscopic control. One of the electrodes was connected to a conventional pre-amplifier (gain, 1) for recording of the membrane potential, and the other to an isolator for supplying a constant inward current pulse of $500 \mathrm{msec}$ every $5 \mathrm{sec}$. The isolator was grounded through the output of the voltage recording pre-amplifier in order to minimize the shunting current of the resting membrane potential. The perfusing media was connected to the virtual ground of the operational amplifier (Tektronix, O-Unit) through the agar bridge, and the actual current flow across the membrane was recorded from the output of the operational amplifier. The intensity of the current pulse $(I)$ and the potential drop across the membrane $(I R)$ were recorded on the polygraph (Grass, 5 or Gould, 440) to compute the conductance of the membrane.

The conductance increase $(\Delta G)$ produced by a transmitter was estimated from the following equation (ONO et al., 1974):

$$
\Delta G=G_{\mathrm{A}}-G_{\mathrm{O}}
$$

where $G_{\mathrm{A}}$ is the maximum overall conductance of the membrane during the response to the transmitter and $G_{\mathrm{O}}$ is the overall conductance of the resting membrane.

All preparations were periodically exposed to $0.05 \mathrm{~mm}$ neostigmine throughout the experiment unless otherwise specified.

\section{RESULTS}

\section{Nicotinic D-cells}

The cells which showed a characteristic depolarization in response to $0.3 \mathrm{~mm}$ nicotine- $2 \mathrm{HCl}$ were identified in $\mathrm{RB}$ group. ACh-induced responses of these cells were readily blocked by equimolar $d$-tubocurarine.

The ACh-induced responses were markedly depressed after the reduction of disulfide bond with a $5 \mathrm{~min}$ application of $1 \mathrm{mM}$ DTT. The response was not restored even after 1 hour washing with the Aplysia Ringer's but was quickly restored after the reoxidation of disulfide bonds with 1 mM DTNB (Fig. 1). The average 
Nicotinic D-type

Control

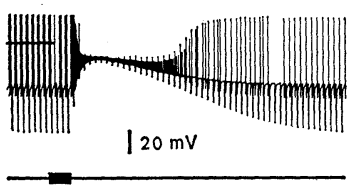

After $1 \mathrm{mM}$ DTT $5^{\prime}$

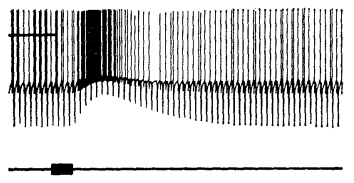

After $1 \mathrm{mM}$ DTNB $5^{\prime}$

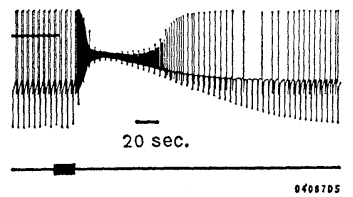

$0.1 \mathrm{mM} \mathrm{ACh}$

Fig. 1. Effects of disulfide bond reduction and reoxidation on the ACh-induced depolarizing response of the nicotinic type. All records were obtained from the same single cell. The downward lines appearing periodically from the base line are the index of the membrane resistance or conductance (see METHODS), and the upward lines are spike firing of the cell. The horizontal bar on the left shoulder of each trace indicates extracellular potential level. The thick portion of the bottom line indicates the time of drug application. The concentration of ACh is kept constant at the value in the control. This nomenclature applies to all other recordings in this paper. The middle and right recordings were made sequentially during the normal Ringer perfusion 20 min after the $5 \mathrm{~min}$ application of $1 \mathrm{~mm}$ DTT and DTNB, respectively. A little shift of the resting membrane potential caused by disulfide bond reduction and reoxidation is adjusted with artificial current flow across the membrane.

response of 10 cells was reduced to $21.4 \pm 9.5 \%$ of the control after a 5 min application of $1 \mathrm{~mm}$ DTT, and then restored to $84.9 \pm 23.1 \%$ of the control after a $5 \mathrm{~min}$ application of $1 \mathrm{~mm}$ DTNB.

In order to examine the location of disulfide bond on the receptor complex, two kinds of thiol reagents were used: one is not site-directed, namely bromoacetamide (BAA); the other is site-directed, namely bromoacetylcholamine bromide (BACA), which has an onium head on one end, a carbonyl radical in a position similar to that of $\mathrm{ACh}$, and a reactive site for sulfhydryl groups on the other end of the molecule.

When the application of DTNB was preceded by $1 \mathrm{~mm}$ BAA, the ACh-response was restored to $98 \%$ of the control, but when it was preceded by $0.01 \mathrm{~mm} \mathrm{BACA}$ the response was restored only to $36 \%$ of the control (Fig. 2). Thus the reducible disulfide bond could be located around $11 \AA$ or less from the anionic binding site, because the molecular length of BACA is nearly equal to that of ACh $(10.6 \AA)$.

Effects of the disulfide bond reduction and reoxidation on the receptor activity was investigated with the dose-response curves (Fig. 3). A high concentration of DTT tended to reduce both the maximum response and the affinity for ACh. The shift of the dose-response curves with the increase in [DTT] was neither type of competitive nor non-competitive inhibition. 


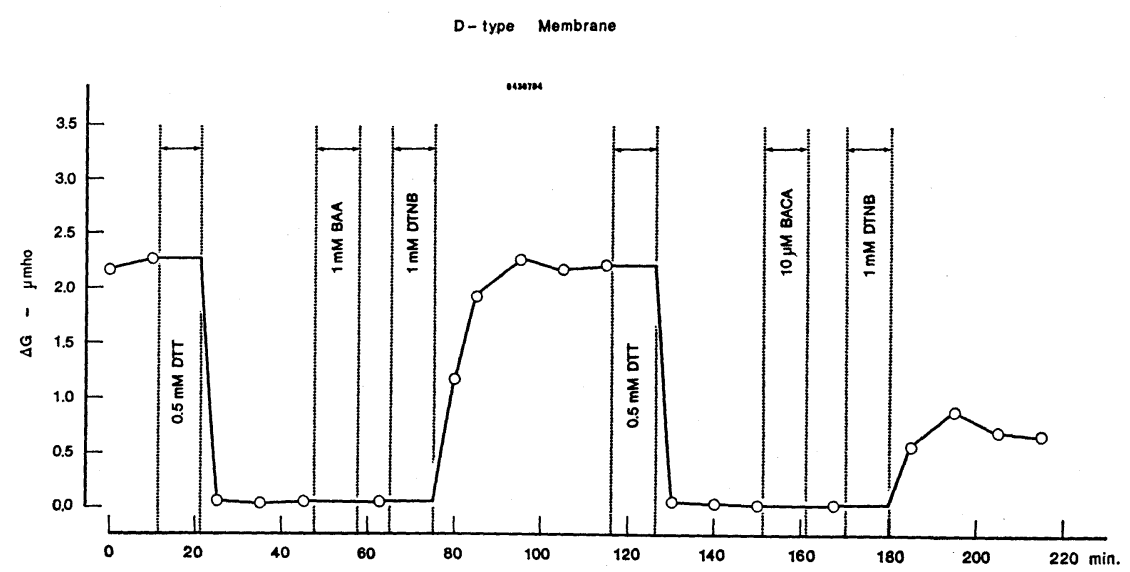

Fig. 2. The time course of the DTT-induced depression of the ACh-response and the recovery from it after DTNB. The ordinate is the conductance increase $(\Delta G)$ produced by $0.1 \mathrm{~mm}$ ACh. The cell was depolarized by ACh. Note that $1 \mathrm{~mm}$ BAA (bromoacetamide) does not affect the recovery by DTNB but $10 \mu \mathrm{M}$ BACA (bromoacetylcholamine) suppresses it distinctly.

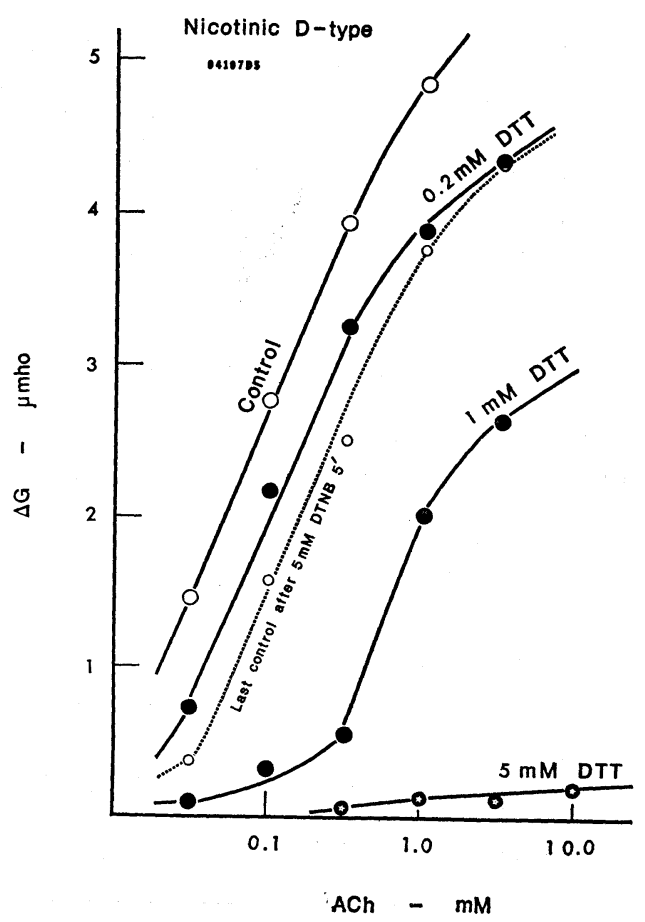

Fig. 3. Effect of DTT on the dose-response curve obtained from a nicotinic D-type cell. Each curve was measured within $40 \mathrm{~min}$ after the $5 \mathrm{~min}$ application of DTT. The preparation was periodically exposed to $0.05 \mathrm{~mm}$ Neo. Note the partial recovery of the response with DTNB after the exposure to $5 \mathrm{~mm}$ DTT (dotted line). 
Nicotinic $H$ - and muscarinic H-cells

The cells which showed a characteristic hyperpolarizing response to either nicotine or arecoline were identified in the RC group and Rl area. The identification of the nicotinic or muscarinic type was confirmed by comparing the blocking potencies of $d$-tubocurarine and atropine. According to KeHOE (1972), the slow IPSP recorded from a pleural ganglion cell can be mimicked by arecoline but not by muscarine. We did not examined this possibility in our preparation but we simply called "muscarinic type" for the convenience of distinguishing it from the "nicotinic type". In fact, the ACh-induced responses of our muscarinic type were readily blocked by atropine but not by $d$-tubocurarine.

Figure 4 shows the effects of the disulfide bond reduction and reoxidation on the two types of ACh-responses. The response of the nicotinic type was decreased by DTT and restored by DTNB, whereas the response of the muscarinic type was little affected by either DTT or DTNB. The average response of 10 nicotinic $\mathrm{H}$ cells was depressed to $30.3 \pm 11.1 \%$ of the control after a 5 min application of $1 \mathrm{mM}$ DTT and it was restored to $89.1 \pm 30.5 \%$ of the control after a 5 min application of $1 \mathrm{~mm}$ DTNB. On the other hand, the average response of 3 muscarinic $\mathrm{H}$-cells was depressed only to $93.7 \pm 15.8 \%$ and restored to $94.1 \pm 9.7 \%$. Such a complete

Nicotinic $H$-type

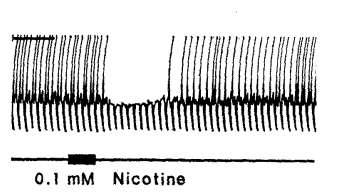

Muscarinic $\mathrm{H}$-type
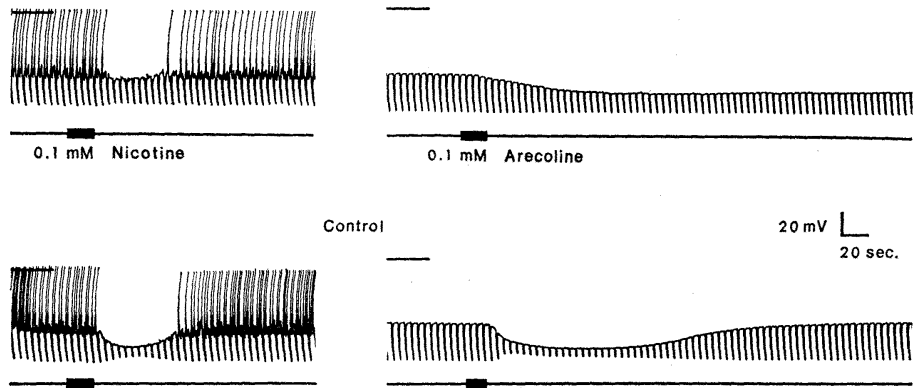

$0.03 \mathrm{mM} \mathrm{ACh}$

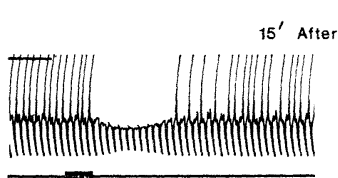

$15^{\prime}$ After $1 \mathrm{mM}$ DTT $5^{\prime}$
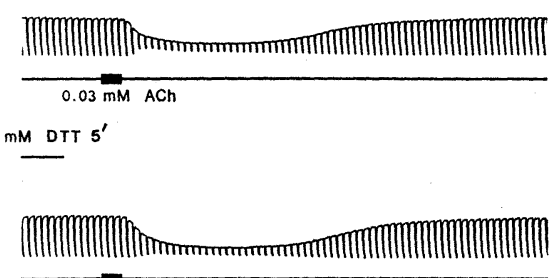

$15^{\prime}$ After $1 \mathrm{mM}$ DTNB $5^{\prime}$
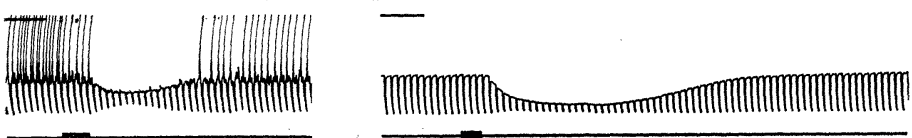

Fig. 4. Effects of disulfide bond reduction and reoxidation on the ACh-induced hyperpolarizing responses. Left and right columns were obtained from a nicotinic and a muscarinic H-type cell, respectively. Note that the response of the nicotinic type was markedly depressed, whereas that of the muscarinic type was not at all. 
difference in susceptibility to DTT was confirmed with all responses to $0.01-$ $0.1 \mathrm{~mm}$ ACh.

The effects of disulfide bond reduction and reoxidation on the nicotinic $\mathrm{H}$ responses were also investigated with the dose-response diagram (Fig. 5). A high concentration of DTT tended to reduce the maximum response as well as the affinity for ACh. Thus the mode of receptor inhibition was neither the competitive nor the non-competitive type.

\section{ACh-esterase and the disulfide bond}

This experiment was to analyze the effect of DTT on the ACh-esterase activity. The relative activity of the esterase was estimated by measuring the relative increase in ACh-response following the application of neostigmine. Before the application of neostigmine, a nicotinic cell was first exposed to $1 \mathrm{mM}$ DTT to reduce the disulfide bonds, then exposed to $1 \mathrm{mM}$ DTNB to reoxidize them. The results confirmed a perfect restoration of the ACh-response after the disulfide bond reoxidation (see Fig. 6). This cell was again exposed to DTT, then exposed to $0.05 \mathrm{~mm}$

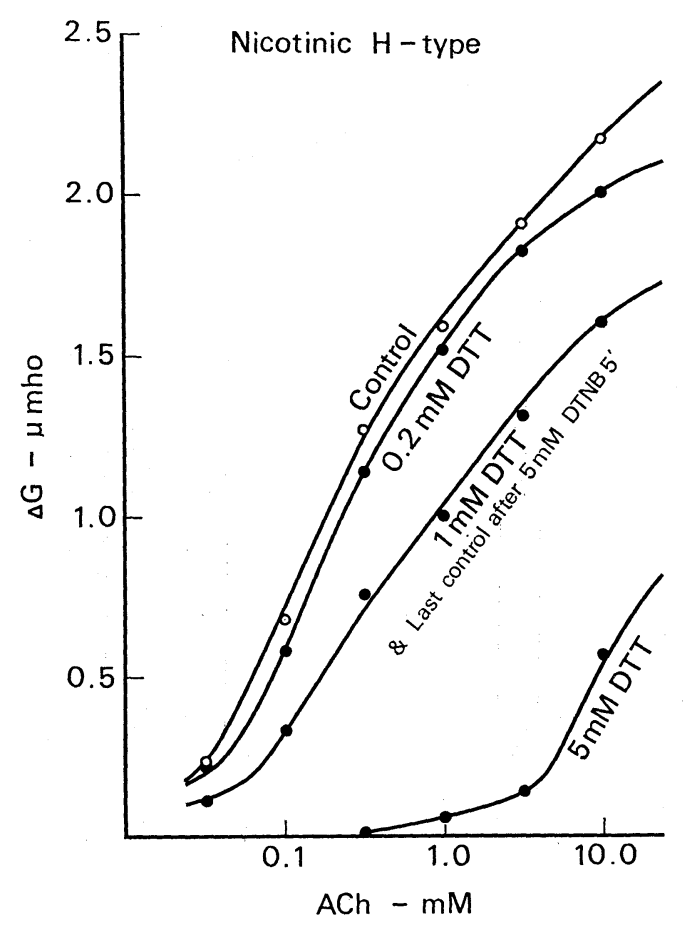

Fig. 5. Effect of DTT on the dose-response curve obtained from a nicotinic H-type cell. Each curve was measured within $40 \mathrm{~min}$ after the $5 \mathrm{~min}$ application of DTT. The preparation was periodically exposed to $0.05 \mathrm{~mm}$ Neo. The partial recovery of the response with DTNB after the exposure to $5 \mathrm{~mm}$ DTT is illustrated with the same curve as that of $1 \mathrm{~mm}$ DTT although the actual points are not shown. 
neostigmine. The ACh-response of the reduced receptor was markedly augmented after neostigmine. After the application of neostigmine, the cell was exposed to DTNB to reoxidize the receptor. The reoxidation markedly enhanced the AChresponse as shown in Fig. 6. However, the relative increase in ACh-response caused by neostigmine was found to be the same as that observed before the receptor reoxidation.

The response of the muscarinic $\mathrm{H}$-cell was not significantly affected by DTT but markedly increased by neostigmine. No further increase with DTNB after neostigmine, however (Fig. 7).

This has been previously confirmed by KARLIN (1967b) with the ACh-esterase obtained from the electric tissue of Electrophorus electricus.

\section{Bromoacetylcholine (BAC)-induced responses on the reduced cells}

The BAC-induced responses on the nicotinic D- and H-cells were depressed by the disulfide bond reduction with 1 mM DTT (Figs. 8 and 9). A small responses to BAC on the muscarinic cell was also blocked by DTT, though the ACh-induced response of the same cell was not affected (Fig. 10). These findings are in contrast with the augmentation or prolongation of the BAC-responses after the disulfide bond reduction observed in the electroplax by SILMAN and KARLIN (1969), and KARLIN (1969).

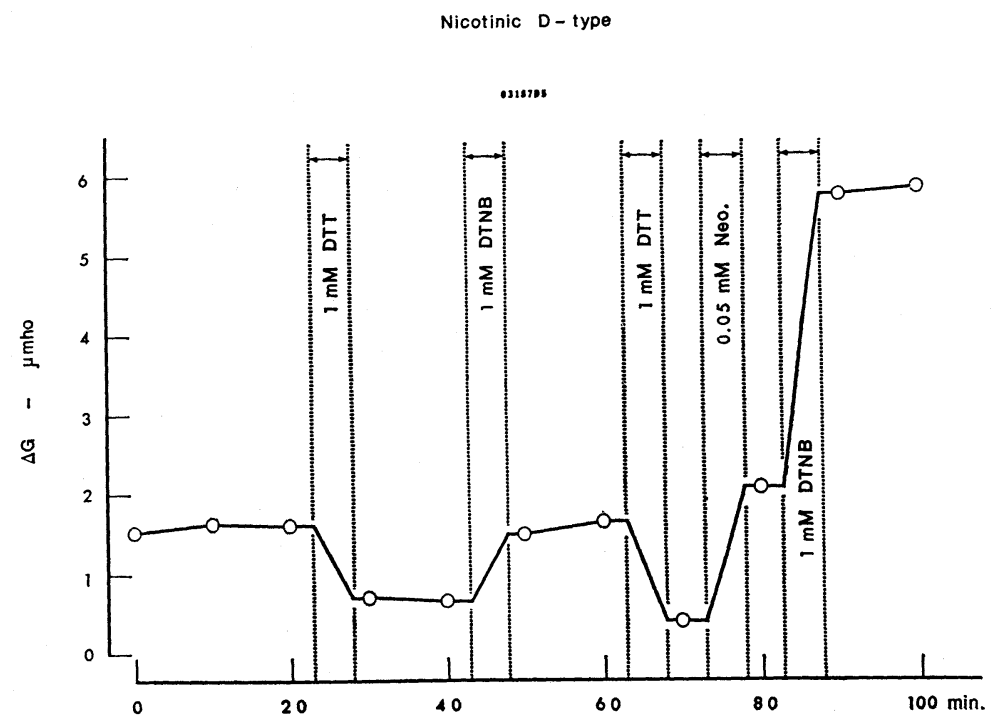

Fig. 6. The time course of the DTT-induced depression of the ACh-response and the recovery from it after DTNB. The ordinate is as same as Fig. 2. The cell was of a nicotinic D-type. Note that this preparation was not exposed neostigmine until the time indicated and that neostigmine is capable of augmenting the response even after the application of DTT as much as it would before DTT. 


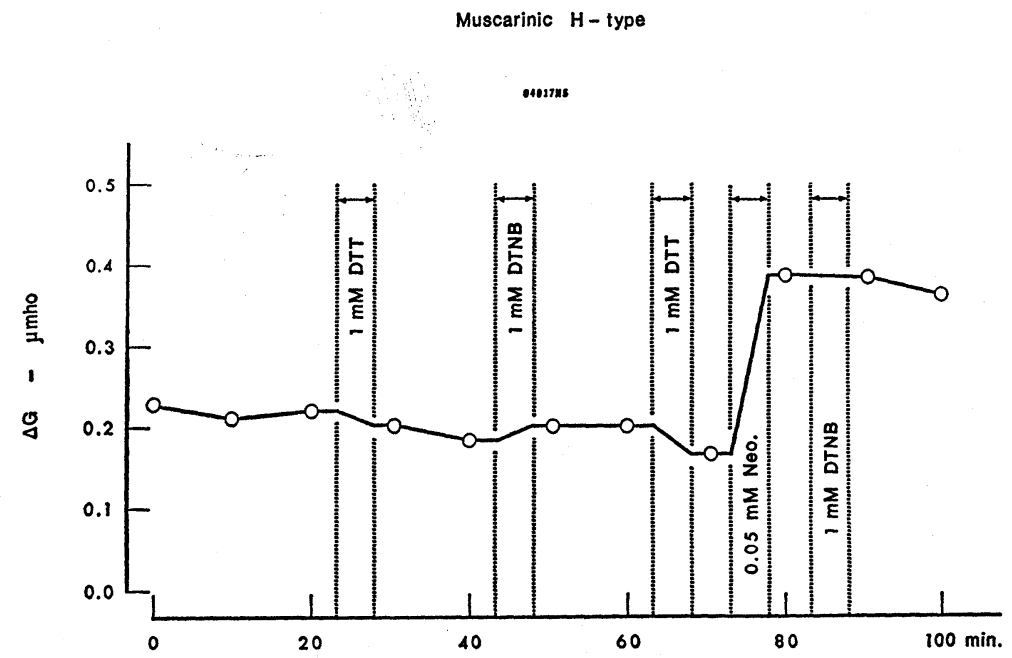

Fig. 7. Same as Fig. 6, but on the muscarinic H-cell. Note that the effect of DTT on the response is insignificant.

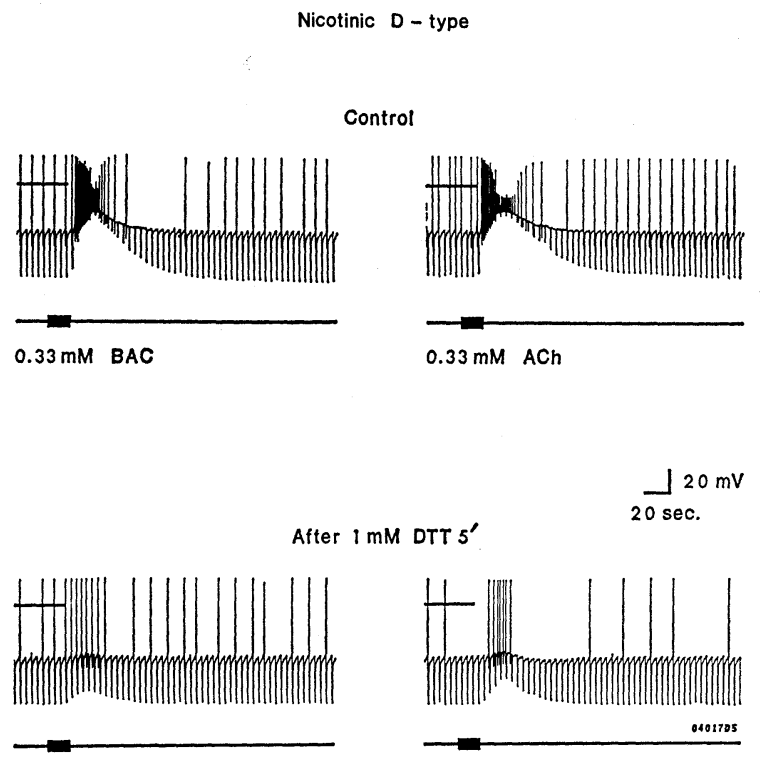

Fig. 8. Effect of DTT on the bromoacetylcholine-induced response (left) as compared with that on the ACh-induced response of the same cell (right). 
Nicotinic $\mathrm{H}$-type

Control
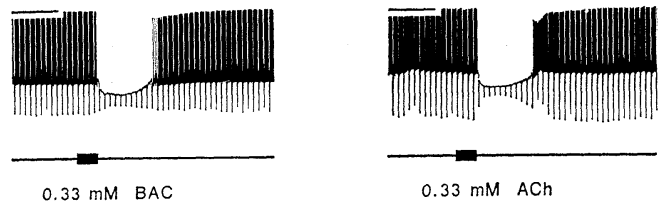

$0.33 \mathrm{mM} \mathrm{ACh}$

After $1 \mathrm{mM}$ DTT 5' $\frac{120 \mathrm{mV}}{20 \mathrm{sec} .}$
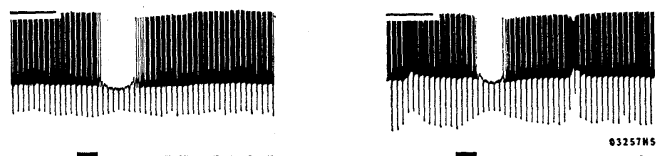

Fig. 9. Same as Fig. 8, but on the nicotinic H-cell.

Muscarinic $\mathrm{H}$-type

Control

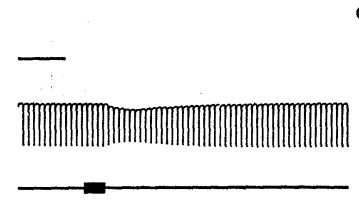

$0.33 \mathrm{mM}$ BAC

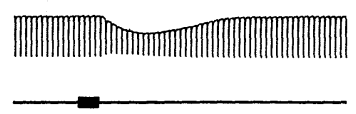

$0.33 \mathrm{mM} \quad \mathrm{ACh}$

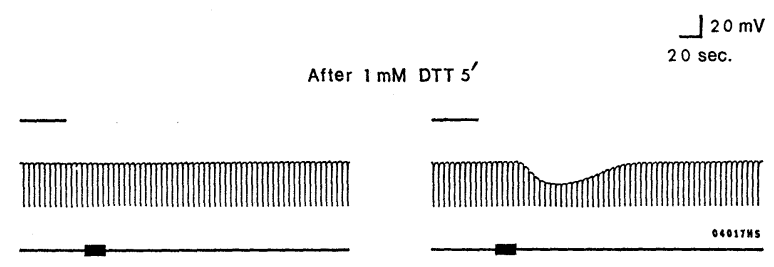

Fig. 10. Same as Fig. 8, but on the muscarinic H-cell. 
Effects of bisonium drugs on the reduced cells

According to KARLIN and WINNIK (1968), a typical nicotinic inhibitor, hexamethonium, becomes an activator for the reduced receptor of the electroplax. However, this was not demonstrable in our experiment with either the nicotinic

Nicotinic $H-$ type

Control
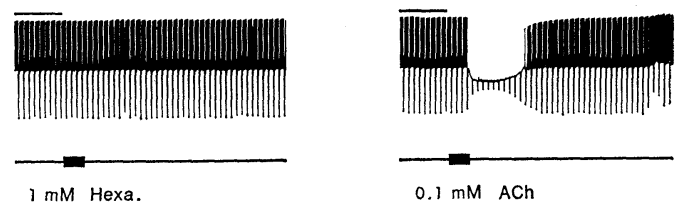

\rfloor $20 \mathrm{mV}$

$20 \mathrm{sec}$.

After $1 \mathrm{mM}$ DTT $5^{\prime}$
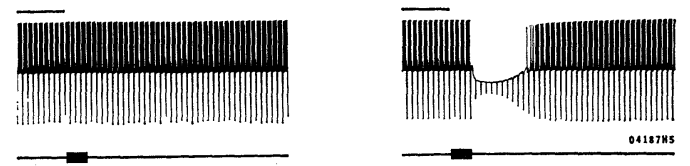

Fig. 11. Effect of hexamethonium on the reduced nicotinic H-cell (left) as compared with that on the ACh-induced response of the same cell (right).

Nicotinic $\mathrm{H}$-type

Control

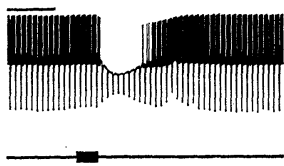

$1 \mathrm{mM}$ Deca.

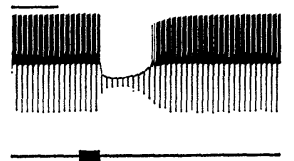

$0.1 \mathrm{mM} \mathrm{ACh}$

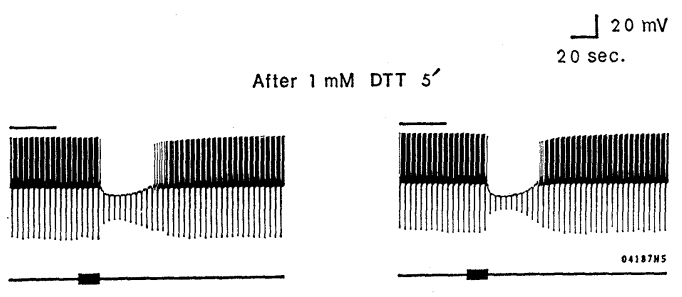

Fig. 12. Effect of DTT on the decamethonium-induced response (left) as compared with that on the ACh-induced response of the same cell (right). 
D-, nicotinic $\mathrm{H}-$, or muscarinic $\mathrm{H}$-cell. One of these negative results was shown in Fig. 11.

KARLIN (1969) has reported that the Deca-induced response of the electroplax was augmented after the reduction of disulfide bonds. However, this was again not reproducible in our experiment with the nicotinic H-cell (Fig. 12). Neither the nicotinic D- nor the muscarinic H-cells responed to Deca before or after the disulfide bond reduction.

Effect of the disulfide bond reduction on the GABA- and the dopamine-induced responses

A certain neurons in RB group are sensitive to GABA and/or dopamine. They are usually hyperpolarized by GABA and/or dopamine but depolarized by ACh. The ACh-induced responses of these cells were confirmed to be of the nicotinic type.

The GABA- and dopamine-induced $\mathrm{H}$-responses were not affected by either DTT (Fig. 13) or DTNB. The ACh-induced responses of the same cells, however, were distinctly reduced by DTT and restored by DTNB, though the results are not shown here.

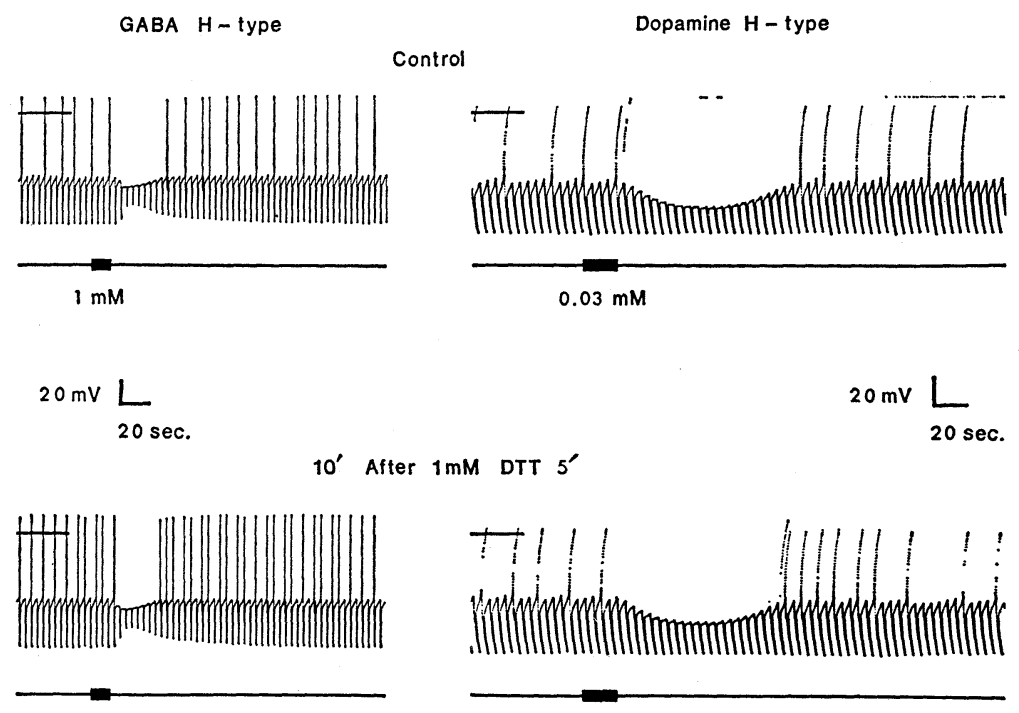

Fig. 13. Effects of disulfide bond reduction on the GABA-induced H-response recorded from a cell (left) and on the dopamine-induced H-response recorded from another cell (right).

\section{DISCUSSION}

Nicotinic receptors. Our results indicate that the ACh-induced responses of the nicotinic receptors including both the excitatory and the inhibitory types are 
readily blocked by a reduction of disulfide bond. This finding suggested that the disulfide bonds in the nicotinic receptors are the crucial elements for the normal process of receptor activation regardless of whether the receptor is of the excitatory or the inhibitory type. The ionic mechanism underlying the activation of the excitatory receptor is known to be completely different from that of the inhibitory receptor (SATo et al., 1968). Nevertheless, the blocking potency of DTT on the excitatory response was found to be approximately the same as that on the inhibitory one. This fact suggested that the disulfide bonds in nicotinic receptors are not directly related to the ion-specific channels. BEN-HAIM et al. (1973) observed a marked depression of the end-plate potentials after the reduction of disulfide bonds. However, they found that their reversal potentials remained unchanged with this treatment. They also considered that the disulfide bonds in the end-plate receptor have a function independent of the activity of the ion-specific channels.

Using site-directed thiol reagents, KARLIN and his co-worker analyzed the localization of disulfide bonds in the ACh-receptor of the electroplax (KARLIN and WINNIK, 1968; KARLIN, 1969). According to them, the disulfide bond is localized within 10 to $12 \AA$ from the anionic site of the ACh-receptors. This has been confirmed in the end-plate receptor of the frog by BEN-HAIM et al. (1973). We also confirmed this on the nicotinic excitatory receptor (Fig. 2) as well as inhibitory one of the ganglion cell (SAWADA and SATO, 1976). Now, it can be generalized that the disulfide bond is an essential and crucial element to all ACh-receptors of the nicotinic type regardless of whether they are of the excitatory or the inhibitory type, and that this bond is localized at a fixed distance from the anionic binding site.

According to KARLIN and WINNIK (1968), hexamethonium, a well known competitive inhibitor of the nicotinic receptor, can activate the same receptor of the electroplax once after the disulfide bond is reduced. Later, RANG and RITTER (1971) confirmed this fact with the muscle preparation of the chick. On the other hand, this was not demonstrable in either the leech muscle (Ross and TrigGLe, 1972) or the sartorius nerve-muscle preparation (BEN-HAIM et al., 1973). We also failed to reproduce this paradoxical action of hexamethonium in either the excitatory or the inhibitory receptor of the Aplysia ganglion cell. Such a discrepancy among the species is probably due to the difference in conformational change of the receptor following the disulfide reduction. For instance, the reduced AChreceptor of the electroplax respond to $\mathrm{BAC}$ with a characteristic long-lasting depolarization and exhibit an augmentation of Deca-induced response (SILMAN and KARLIN, 1969; KARLIN, 1969). These peculiar actions of BAC and Deca were not demonstrable in our nicotinic preparation. Additional structural difference of the receptor between the electroplax and the Aplysia ganglion cell has been shown in the cooperativity; the Hill coefficient obtained from the electroplax was 2 (KARLIN, 1967a, 1969), whereas that from the Aplysia ganglion cell was 1 (SATo and SATo, 1976a, b).

Muscarinic receptors. Classically, the muscarinic receptors are known to be 
highly responsive to muscarine, oxotremorine, pilocarpine, and arecoline, while their responses are readily blocked by atropine and hyoscine. Recently, however, these pharmacological conditions have been found not applicable to all muscarinic receptors. For example, some receptors are highly responsive to arecoline but not to muscarine and their responses are readily blocked by methylxylocholine but not by atropine (КеноE, 1972). We don't know whether it is adequate to call such receptors as "muscarinic". We were able to identify a few neurons which are highly responsive to arecoline and are readily blocked by atropine. All of these neurons were slowly hyperpolarized by $\mathrm{ACh}$ but no response to nicotine. As described in RESULTS, we simply named these receptors as "muscarinic" although we did not examine further pharmacological characteristics.

It should be noted that the ACh-induced responses of these cells were not appreciably affected but sometimes slightly augmented by the disulfide bond reduction. Using more typical muscarinic preparation, the ileal muscle strips of guineapigs, KUHNEN-CLAUSEN (1975) investigated the effect of disulfide bond reduction on the acetyl- $\beta$-methylcholine-induced responses. According to her, the muscular contraction was not depressed but sometimes slightly enhanced after the disulfide bond reduction. Her results obtained from the excitatory receptors are consistent with our results from the inhibitory receptors. Now, we can postulate that the disulfide bonds are not essential elements for the normal operation of the muscarinic receptors regardless of whether the receptor is of the excitatory or the inhibitory type.

Non-cholinergic receptors. The GABA- and dopamine-induced responses of the inhibitory type were not affected by the disulfide bond reduction, as shown in RESUlTS. Using the crab neuromuscular junction, BEN-HAIM et al. (1973) studied the effects of DTT on the non-cholinergic transmission. The actual transmitters were supposedly GABA and glutamate although they were not identified. According to them, the postsynaptic responses of both excitatory and inhibitory types were not depressed at all by the disulfide bond reduction.

These negative results from various kinds of non-cholinergic receptors appear to suggest that the disulfide bond is an important element exclusive to the nicotinic receptors, although further analysis needs to be done on the serotonergic and catecholaminergic receptors.

We express our cordial thanks to Dr. I. Silman for sending us the drugs BAA, BACA, and $\mathrm{BAC}$, and to Mr. Thomas R. Alexander for assisting in our experiment with his excellent technique. This work was supported in part by United States Public Health Service Research Grant No. 5R01-NS01687-16 and 17, Foundation for In-Service Training and Welfare of Private School Personnel in Japan, and by the Naito Research Grant for 1973.

\section{REFERENCES}

Albuquerque, E. X., Sokoll, M. D., Sonesson, B., and Thesleff, S. (1968) Studies on the nature of the cholinergic receptor. Eur. J. Pharmacol., 4: 40-46.

Ben-Haim, D., Landau, E. M., and Silman, I. (1973) The role of a reactive disulfide bond in the function of the acetylcholine receptor at the frog neuromuscular junction. J. Physiol. 
(Lond.), 234: 305-325.

Cleland, W. W. (1964) Dithiothreitol. A new protective reagent for SH groups. Biochemistry (N.Y.), 3: 480-482.

Del Castillo, J., Escobar, I., and Gijón, E. (1971) Effects of the electrophoretic application of sulfhydryl reagents to the endplate receptors. Int. J. Neurosci., 1: 199-209.

Ellman, G. L. (1959) Tissue sulfhydryl groups. Arch. Biochem. Biophys., 82: 70-77.

Frazier, W. T., Kandel, E. R., Kupferman, I., Waziri, R., and Coggeshall, R. (1967) Morphological and functional properties of identified neurons in the abdominal ganglion of Aplysia californica. J. Neurophysiol., 30: 1288-1351.

Kalderon, N. and Silman, I. (1971) Affinity labelling of the acetylcholine receptor in the electric eel using bromoacetyl derivatives related to acetylcholine. Israel J. Chem., 9: 1213BC.

KARLIN, A. (1967a) On the application of "a plausible model" of allosteric proteins to the receptor for acetylcholine. J. Theor. Biol., 16: 306-320.

KARLIN, A. (1967b) Chemical distinctions between acetylcholine-esterase and the acetylcholine receptor. Biochim. Biophys. Acta, 139: 358-362.

KARLIN, A. (1969) Chemical modification of the active site of the acetylcholine receptor. J. Gen. Physiol., 54: 245S-264S.

KARLiN, A. and BARTELs, E. (1966) Effects of blocking sulfhydryl groups and of reducing disulfide bonds on the acetylcholine-activated permeability system of the electroplax. Biochim. Biophys. Acta, 126: 525-535.

KARLIN, A. and Winnik, M. (1968) Reduction and specific alkylation of the receptor for acetylcholine. Proc. Natl. Acad. Sci. U.S.A., 60: 668-674.

KeHoE, J. S. (1972) Three acetylcholine receptors in Aplysia neurons. J. Physiol., 225: 115146.

KuHNen-Clausen, D. (1975) Regulatory properties and cooperativity of membrane bound muscarinic receptors of intestinal smooth muscle cells. CCACAA, 47: 465-474.

Mittag, T. W. and Tormay, A. (1970) Disulfide bonds in nicotinic receptors. Fed. Proc., 29: 574.

Ono, H., Sato, M., and Maruhashi, J. (1974) The cholinergic excitatory and inhibitory postsynaptic responses of Aplysia ganglion cells during and after Lithium-Ringer perfusion. J. Neurobiol., 5: 43-63.

RANG, H. P. and RitTer, J. M. (1971) The effect of disulfide bond reduction on the properties of cholinergic receptors in the chick muscle. Mol. Pharmacol., 7: 620-631.

Ross, D. H. and Triggle, D. J. (1972) Further differentiation of cholinergic receptors in leech muscle. Biochem. Pharmacol., 21 : 2533-2536.

Sato, M., Austin, G., YaI, H., and Maruhashi, J. (1968) The ionic permeability changes during acetylcholine-induced responses of Aplysia ganglion cells. J. Gen. Physiol., 51: 321-345.

SAto, T. and SAto, M. (1976a) Effects of the disulfide bond reduction on nicotinic depolarizing receptors in Aplysia neuron. J. Physiol. Soc. Japan, 38: 50 (in Japanese).

SAto, T. and SAto, M. (1976b) Effects of the disulfide bond reduction on nicotinic and muscarinic hyperpolarizing-cells in Aplysia abdominal ganglion. J. Physiol. Soc. Japan, 38: 59P.

SAwAdA, M. and SATo, M. (1976) The significance of disulfide bonds in the cholinergic receptors of the Aplysia ganglion cells. J. Physiol. Soc. Japan, 38: 84P (in Japanese).

Silman, I. and KARLIN, A. (1969) Acetylcholine receptor: covalent attachment of depolarizing groups at the active site. Science, 164: 1420-1421.

TAUC, L. and Gerschenfeld, H. M. (1962) A cholinergic mechanism of inhibitory synaptic transmission in a molluscan nervous system. J. Neurophysiol., 25: 236-262. 